\title{
THE AMERICAN IRON TRADE OF 1909 AND THE OUTLOOK
}

\author{
By A. I. FindLey, \\ Editor "The Iron Age," New York City.
}

The recovery in the iron trade of the United States from the depression beginning with the panic of October, 1907, has been unparalleled in the history of such periods. In the summer months of this year the view was expressed that the revival in demand had come too soon after a serious unsettling of confidence to be considered the real beginning of another period of prolonged prosperity. The so-called Sunshine Movement of 1908 and the false starts that came with it were one reason for doubting the permanence of this year's improvement. There was a disposition in some quarters, in fact, to find a resemblance between the behavior of the market this year and the effervescent demand which came in 1895 , two years after the panic of 1893 , and vanished before the year was out. But the developments of the past three months have shown that the present movement has far more back of it than supported the little boom of 1895. Apart from the palpable signs of strength in the iron market itself, the present situation differs vastly from that of I895 in respect to credit, soundness of the currency basis, the crops, the buying power of the country, and its capacity for adding to its wealth, saying nothing of the greater confidence in financial institutions.

What is said above refers not at all to the tremendous increase in the scale of iron and steel consumption in the United States since I895, expressed by a ratio of about three to one, but to the state of health in finance and industry to-day as contrasted with the diseased condition that persisted in the years following the crash of 1893 . Whatever may have been the opinion of some students of the situation in the iron trade two or three months ago, it is now plain that practically but one ground exists for comparing the movements of 1895 and 1909 - the fact that an interval of two years separates each from a severe monetary panic.

It is not necessary, in writing of the revival in the iron trade, (496) 
to go at length into the causes of the late depression. Yet there can be no ignoring its railroad phases. Every estimate of iron trade conditions and prospects in the past two years has begun and ended with the railroads. Last year's prophets of an early return of prosperity, who said that the unsound methods of a few New York banks should not stop the wheels of industry all over the country, saw at length that it was more than a local affair and more than the penalty of bad banking. What the iron trade found out at heavy cost was that railroad demand, one of the strong props of the prosperity of 1906 and 1907, had all but disappeared. There was no escaping the conclusion that the Hepburn act and the various official notifications that it was but a fair beginning in the application of untried policies to the operation of railroads, had raised a serious question as to the value of railroad securities. It is now evident that while that doubt has not altogether disappeared, a saner view is taken of the whole railroad problem. That may be some compensation for two years of hardship. Railroad financing over long periods is again possible on terms which can be entertained, not only for the refunding operations and note redemptions which were common earlier in the year, but for the new track, new bridges and new equipment which all the large systems are now planning or have actually under construction.

As in all other periods of recovery the abundance of money, due to the enormous accumulations in banks in the many months during which industry has languished, is an important factor. It is true that thus far much of these accumulations have been devoted to a vast speculation in securities, but even this use, much as it has been deprecated, has not been without its stimulating effect upon the business situation. The common stock of the United States Steel Corporation has been in a spectacular way the leader in this speculative movement. No such gigantic operation for the lifting of a security value has ever been conducted and no other has been so successful. There is no question that the psychological factor in the advance of Steel common from $2 \mathrm{I} 7 / 8$ in October, I907, to a fraction over 90 in September, 1909, has been an influence in the market for iron and steel products. It was evidently the belief of powerful financial interests that the actual demand for the products of blast furnaces and rolling mills would speedily overtake the speculative movement, so that the values established by the latter 
through skilful manipulation and the command of an enormous supply of cheap money, would in time be justified by the market for steel itself. Unquestionably this belief thus backed had no little to do in creating confidence in the continuity of the recovery that set in plainly in the spring of 1909 .

Opinions will differ as to the extent to which the making of an open iron and steel market in February of this year has figured in the expansion of demand in the past six months. Those who consistently believed in the price maintenance policy of rgo 8 have been disposed to say that confidence was returning and that the time was ripe for a larger consumption. There were others who believed, as Andrew Carnegie did, that "the way to lift the market is to get under it." They considered that the only way to end the hesitation in demand, which they held due in part to doubt of the ability of the steel manufacturers by lawful co-operation to hold prices close to the level of 1907 , was to make such cuts as would attract buyers. It was known for weeks before the open market announcement of February I8, I909, that the co-operative movement was seriously threatened. Nominal market prices had been cut from $\$ 1.00$ to $\$ 3.00$ a ton, some of the smaller companies leading in these reductions. The sales managers of the various subsidiary companies of the United States Steel Corporation had been urgent for some time in appeals for permission to meet the prices of their competitors. The decision of the United States Steel Corporation that it would no longer maintain prices was announced by Judge Gary, its chairman, on February Igth. Of the reasons for this course he said:

It appears that, for one reason or another, including particularly the tariff agitation, many of the smaller concerns who have not been disposed to co-operate during the last year have become more or less excited and demoralized, and have been selling their products at prices below those which were generally maintained. This feeling has been somewhat extended and has influenced unreasonable cutting of prices by some of those who were opposed to changes but felt compelled to meet conditions in order to protect their customers. As a result of these conditions there has been a material decrease in new business during the last month for the reason, as stated by consumers, that they proposed to wait until after they were satisfied bottom prices had been reached.

In view of the circumstances stated, and the further fact that the stocks on hand at the time the panic occurred have been disposed of and the contracts 
in force at that time have been completed or taken care of so that the necessities for the maintenance of prices which formerly existed have been modified, the leading manufacturers of iron and steel have determined to protect their customers, and for the present at least sell at such modified prices as may be necessary with respect to different commodities in order to retain their fair share of the business. The prices which may be determined upon and the details concerning the same will be given by the manufacturers to their customers direct as occasion may require.

In the week following the appearance of the above statement the prices of nearly all iron and steel products fell several dollars a ton. The price of steel rails, however, was held at the $\$ 28.00$ level for Bessemer rails and has remained there. The pig iron market had been practically an open one throughout the depression, and yielded but little when the finished material price structure fell. On most grades of pig iron the early reduction in February amounted to fifty to seventy-five cents a ton. For a time users of finished material bought sparingly, as they had done before, believing that it would take some time for prices to touch bottom. Successive reductions in mill products came in March, April and May. The low point for most products was reached in the last named month.

Fluctuations in Iron and Steel Prices in 1907 and $1909 .{ }^{2}$

\begin{tabular}{|c|c|c|c|}
\hline Bessemer pig iron & $\begin{array}{l}\text { High, } \\
\text { 1907. } \\
\$ 23.28\end{array}$ & $\begin{array}{l}\text { Low, } \\
\text { I g09. } \\
\$ \text { I } 4.58\end{array}$ & $\begin{array}{c}\text { Oct. } 1 \text {, } \\
1909 . \\
\$ 17.50\end{array}$ \\
\hline Basic pig iron $\ldots \ldots \ldots \ldots \ldots \ldots \ldots \ldots$ & 23.00 & I4. I 2 & 16.50 \\
\hline Southern No. 2 foundry iron ..... & 26.00 & 14.25 & 17.75 \\
\hline Bessemer billets $\ldots \ldots \ldots \ldots \ldots \ldots \ldots$ & 30.00 & 22.00 & 25.50 \\
\hline Rails $\ldots \ldots \ldots \ldots \ldots \ldots \ldots \ldots \ldots \ldots \ldots \ldots \ldots \ldots \ldots$ & 28.00 & 28.00 & 28.00 \\
\hline Plates $\ldots \ldots \ldots \ldots \ldots \ldots \ldots \ldots \ldots \ldots \ldots$ & 1.70 & I. Io & I.50 \\
\hline Structural shapes $\ldots \ldots \ldots \ldots \ldots \ldots$ & 1.70 & I. Io & 1.50 \\
\hline Merchant bars $\ldots \ldots \ldots \ldots \ldots \ldots \ldots \ldots$ & I.60 & 1.05 & I.40 \\
\hline Sheets, 28 gauge $\ldots \ldots \ldots \ldots \ldots \ldots \ldots$ & 2.55 & 2.10 & 2.30 \\
\hline Tinplates $\ldots \ldots \ldots \ldots \ldots \ldots \ldots \ldots \ldots \ldots \ldots$ & 3.85 & 3.45 & 3.55 \\
\hline Plain wire. & 1.90 & 1.40 & 1.60 \\
\hline Pipe, $3 / 4$ to 6 in. ....... & 2.47 & $1.8 \mathrm{I}$ & г.8I \\
\hline
\end{tabular}

An idea of the movement of prices in the past two years may be obtained from the foregoing table, in which Pittsburgh prices are represented, except in the case of pig iron. For Bessemer and basic

1Prices for pig iron, billets and rails in dollars per gross ton; prices of other products in dollars per 100 pounds. 
pig iron the 1907 price is the average price at Mahoning or Shenango Valley furnace for the high month of that year, while the 1909 price in the next column is the average in the "Valleys" for the low month in that year. The freight from the "Valleys" to Pittsburgh is ninety cents a ton. In the case of Southern No. 2 foundry iron the price given is for Cincinnati delivery. The prices in the third column are all as of October I, 1909.

Perhaps the most marked response to the reductions in steel prices was noticed in the market for structural steel. Fabricating companies made low bids on building contracts in 1908 , so low in fact as to indicate plainly that some steel manufacturers were furnishing them structural shapes at considerably less than the prices ostensibly maintained for the latter by the co-operative movement. When steel prices were openly cut this year further reductions were made in structural steel, and these stimulated the placing of orders for new buildings and bridges. Large contracts for bars were placed also in the spring of this year, some of these running to the middle of I9Io. There was good buying, too, of wire products, but the most pronounced movement in these came just after May Ist, when reductions of $\$ 4.00$ a ton in wire nails were announced and of $\$ 7.00$ a ton in barb wire.

Buying by the railroads was not particularly stimulated by the cuts in prices. Occasional orders were placed for new cars and locomotives, but it was the general report that the railroads were not in need of new rolling stock. However, as the buying movement in the iron trade broadened and demands upon the railroads increased, new equipment orders became more frequent. At this writing most of the car works have orders enough to keep them busy until the end of the year. For most of 1906 their books showed that their capacity was engaged for about twelve months ahead. This was true, also, in the early part of 1907.

Perhaps the best measure of the recovery in the iron trade this year is found in the statistics of pig iron production. At the beginning of 1909 the blast furnaces of the country were producing at the rate of $21,000,000$ tons of pig iron a year. On September $I$, the rate had increased to $27,750,000$ tons a year, with additional furnaces going into blast each week, indicating that new records would be made in September and October. The greatest pig iron production in the United States for a year was $25,78 \mathrm{I}, 36 \mathrm{I}$ tons in 
1907. While 1909 is likely to fall more than $\mathrm{I}, 000,000$ tons short of this the indications are that the 1907 record will be considerably exceeded in I9Io.

Mention should not be omitted of the effect of the February reductions in steel prices on the wages of iron and steel workers. All the important steel companies apart from those included in the United States Steel Corporation reduced wages ten per cent, making the new rate effective April I, and in some cases similar reductions were made in all salaries from president down. A number of blast furnace companies in the Central West and in Central and Eastern Pennsylvania made reductions also, though for the most part blast furnace wages were readjusted in 1908 as prices for pig iron fell. One of the most noteworthy of all the surprising phenomena of 1909 was the prompt restoration of wages by iron and steel companies. The general expectation that the United States Steel Corporation would reduce wages was not realized. Accordingly in May and June announcements were made by the varions other steel companies that the wages of their employees would be restored to the basis existing before April I. The marked improvement in business was the reason generally given for these restorations, in spite of the fact that some of the steel companies had been forced to make prices leaving little profit, in the sharp competition for orders. It was recognized, however, that the cost of living was persistently high and that after the short working time and short pay of 1908 steel workers were ill prepared to stand a general reduction in wage rates.

Though much was said about the tariff in comments on the course of the iron trade in the early part of this year, the downward revision of iron and steel duties in progress at Washington was really not an important influence. The effect of the PayneAldrich tariff act, as passed in August, is thus far scarcely appreciable in the iron trade. The best opinion is that under ordinary conditions foreign iron and steel products, even under the new duties, need not be expected to enter the United States in any significant quantity. The difference between ordinary market prices abroad and those in the United States is not sufficient to warrant the cost of transportation from foreign steel works, the payment of the duties and the perietration of foreign pig iron or finished products any considerable distance into the interior of this 
country at competitive prices. The Atlantic seaboard, in fact, may be considered practically immune from competition except when domestic prices are pushed up rapidly under the impetus of a boom. The Pacific slope is most exposed, but there the tonnage involved is relatively small. When any large orders come up in that territory it may be expected that our iron and steel works nearest the Pacific, or even those in the Chicago district, would make any concessions needed to hold the business at home. The chief possibility of the reductions in the metal schedule is the cutting off of part of the peaks in prices reached in boom times.

Of actual developments thus far on which the new tariff has a bearing, the most important is the report that a large Pacific coast steamship interest has bought 50,000 tons of Chinese pig iron and is now placing it with consumers in that district. A certain amount of Chinese pig iron, as well as foundry iron produced in Great Britain, has been imported on the Pacific Coast in recent years. In view of the high cost of transportation to the coast from domestic centers of pig iron production, importation has been advantageous and is more so now that the duty has been reduced from $\$ 4.00$ to $\$ 2.50$ a ton. On the Atlantic seaboard the rapid advance in the price of domestic pig iron suggested to a number of buyers as early as August of this year the advisability of importing iron from the Middlesbrough district in England. The low state of the British iron market in the eighteen months preceding had brought values down to an attractive level. Middlesbrough No. 3 foundry iron, for example, was selling at fifty shillings in August. Early in September arrangements were made for bringing in several thousand tons of this grade, which corresponds to No. 2 foundry iron in the United States, at $\$ 17.50$, duty paid. At that time deliveries of No. 2 domestic pig iron at plants of tidewater consumers were on a basis of $\$ \mathrm{I} 7.75$ to $\$ 18.00$. It is a question how far the import movement will go. Already advances have been made in Great Britain, due to expectations of further American demand. It is always the experience that higher prices abroad follow advances here. Whether these will now be rapid enough to check the shipment of iron to the United States will depend in part on the extent of the actual accompanying improvement in consumption in Great Britain.

The possibility of imports of scrap iron and steel is also of 
interest in view of the reduction of duty on such material from $\$ 4.00$ to $\$ 1.00$ a ton. The rapid increase in the production of basic open hearth steel in the United States in recent years, and the large employment of scrap iron in the manufacture of such steel has created a comparative scarcity of what is known in the trade as "heavy melting steel scrap." Eastern steel works in particular found the advance in the price of this material an embarrassment and naturally such companies favored the reduction in the scrap duty as a means of holding in check the domestic scrap market. Arrangements have already been made for bringing in several thousand tons of "bloom ends" from the Middlesbrough district in England, and it is believed that a considerable movement of South American and Mexican scrap into the United States may yet be seen, in addition to imports from Germany and Great Britain.

Every revival in the iron trade like the present one brings up the question of the immediate and prospective relation of consumption to producing capacity. It is not the habit of iron and steel companies to enter upon new programmes of construction in slack times. But it has often been noticed that new rolling mills, steel works and blast furnaces on which work was started in a boom are nearly ready to produce when the break comes and thus have to be reckoned with when demand again shows signs of strength. Another fact about the American iron trade which should be put alongside this one is that the potential consumption which the iron trade faces on emerging from a period of depression is not that which existed when prosperity departed. Not only in every such interval is there a gain in population, but new uses for iron and steel are developed. Thus as the tide of prosperity rises again it is with the certainty that a new high point will be reached on the ensuing movement.

The United States Steel Corporation was the chief builder of new capacity in the recent depression. Its appropriations for new construction out of the earnings of prosperous years were enormous. The plan was that the works at Gary, Indiana, which are counted on, as now laid out, to add 2,500,000 tons a year to the Steel Corporation's product, should be pushed ahead regardless of conditions in the iron trade. In deciding on these works the Corporation's officers took account of the average increase in iron and 
steel consumption in the United States over a period of years. They decided that there were advantages in building in times of depression, even though the capacity should not be immediately needed. Comparatively little was done in new construction in I908 by the independent steel companies. Some of them had just finished additions before the panic broke, others had plans for extensions which in some cases were held in abeyance last year, but were taken up in the early part of Igog. The result is that the iron trade enters upon a new period of prosperity with a considerably increased ability to produce pig iron, steel and finished material. Further, construction now under way and plans about to be carried out will bring forward other new plants at intervals in the next twelve months. It is reckoned that at the beginning of 1907 the effective blast furnace capacity that could be simultaneously worked was capable of producing $26,400,000$ tons of pig iron a year. In 1907 fifteen new furnaces were put in blast, with an annual capacity of 2,050,000 tons of pig iron. In 1908 eleven new furnaces were started up, with a capacity of $1,300,000$ tons a year; in the first nine months of 1909 nine new furnaces, with a capacity of I,250,000 tons a year. In addition fourteen blast furnaces of modern capacity are under construction, while twelve furnaces are being rebuilt and enlarged. Thus by the early part of I9Io our pig iron production could reach $33,000,000$ tons a year, as against a production on October I, I909, at the rate of about $29,750,000$ tons a year. Much of the blast furnace construction referred to above is accompanied by new steel works capacity and new rolling mills, the latter representing a proper increase in the production of various finished forms of iron and steel. It is plain, therefore, that demand may still increase materially in the next twelve months without putting the industry under such strain as was experienced in the first half of I907.

The predictions of leaders in the iron trade concerning I9Io are highly optimistic. These are not based on the amount of business actually booked for next year, for that is not great as yet. The reasoning of those who predict the greatest year the iron trade has ever seen is this: with partial recovery from the depression the iron industry is making a record production in the closing months of I909. Even allowing that the present movement represents in part the rebuilding of depleted stocks, continued recovery, following the 
marketing of enormous crops, will carry the iron trade well past its best record. The steel manufacturers made every effort to prevent speculative buying at the low prices of four months ago. For the most part deliveries were limited to 1909. Already orders for 800,ooo tons of rails have been entered for I9IO, and it is expected that further large purchases will soon follow. The rail mills have done little better in 1909 than in 1908 . Their production in the latter year was about $1,900,000$ tons, as against a record of 3,977,000 tons in 1906 , and a total of $3,633,000$ tons in 1907 . The prediction that 1910 will make a new record in rail production is based on the idea that that year must compensate for the restricted purchases of 1908 and I909.

Cautions are already being sounded, in view of the rapid advance of prices for iron and steel in the past month. Particularly has the pig iron market shown signs of excitement. There is a feeling that if the buying movement covering pig iron deliveries for the first quarter and first half of I9Io goes on at the pace of the last half of September it will be succeeded by a reaction that can only retard healthy recovery. All raw material markets seem to be affected by the high expectations entertained for the coming year. Prices of coke for delivery in 1910 are now nearly double those touched at the low point last year. The expectation of Lake Superior ore shipments in 1909 entertained early in the season was about 35,000,000 tons, as against record shipments in 1907 of 42,245,000 tons. Predictions are now made that this year's shipments will exceed $40,000,000$ tons and may come close to the total for 1907 . Whereas authorities in the ore trade were quite convinced last year that a period of years would elapse before the demand upon Lake Superior mines would approach that of 1907, they now believe that it will be much exceeded in I9Io.

In connection with the lake ore movement it should be noted that Eastern Pennsylvania blast furnaces are now importing iron ore from Cuba, Newfoundland, Sweden and Spain to an extent that makes them almost independent of the Lake Superior supply. Heretofore they have bought from $\mathrm{I}, 000,000$ to $2,500,000$ tons of lake ore a year. The present indications are that the low prices at which foreign ores can be delivered, due in part to the reduction in the iron ore duty from forty cents to fifteen cents a ton, will result in imports of fully $2,500,000$ tons of iron ore in I910, whereas in three 
years only have importations exceeded $1,000,000$ tons, the high record being about $I, 300,000$ tons.

The iron trade in both Germany and Great Britain has been favorably affected by recent developments in the United States. In Germany complications over the existing iron and steel pools must be reckoned with in any calculations for I910. There were evidences of a certain amount of dumping of German steel in Great Britain last year, and in semi-finished steel the movement has persisted in I909. The steel manufacturers of the United States, however, are quite persuaded that there is no profit immediate or ultimate in dumping material on foreign markets. The operations of the United States Steel Products Export Company, which conducts the export trade of the United States Steel Corporation's subsidiaries, have been steadily carried on with a view to making a profit. This company did not increase its exports in 1908 and Igog because of the lessened demand at home, but rather sent less steel abroad, accepting the foreign situation as it found it. On the next upward movement at home it may be expected to follow the policy of 1906 and 1907, when it vigorously pushed its foreign trade, in contrast with the old time policy of withdrawing from foreign markets when home demand was extraordinary. 